

\title{
Hydraulic and chemical evolution of GCLs during filter press and oedopermeametric tests performed with real leachate
}

\author{
S. Rosin-Paumier, N. Touze-Foltz
}

\section{- To cite this version:}

S. Rosin-Paumier, N. Touze-Foltz. Hydraulic and chemical evolution of GCLs during filter press and oedopermeametric tests performed with real leachate. Geotextiles and Geomembranes, 2012, 33, pp.15-24. 10.1016/j.geotexmem.2012.02.002 . hal-01717764

\section{HAL Id: hal-01717764 \\ https://hal.science/hal-01717764}

Submitted on 18 Jun 2018

HAL is a multi-disciplinary open access archive for the deposit and dissemination of scientific research documents, whether they are published or not. The documents may come from teaching and research institutions in France or abroad, or from public or private research centers.
L'archive ouverte pluridisciplinaire HAL, est destinée au dépôt et à la diffusion de documents scientifiques de niveau recherche, publiés ou non, émanant des établissements d'enseignement et de recherche français ou étrangers, des laboratoires publics ou privés. 


\title{
Hydraulic and chemical evolution of GCLs during filter press and oedopermeametric tests performed with real leachate
}

\author{
$\underline{\text { S. Rosin-Paumier }}{ }^{\mathrm{a}, \mathrm{b}^{*}}$, N. Touze-Foltz ${ }^{\mathrm{b}}$ \\ a Laboratoire Environnement, Géomécanique \& Ouvrages, Institut National Polytechnique de \\ Lorraine, B.P. 40, 54501 Nancy, France \\ ${ }^{\mathrm{b}}$ Hydrosystems and Bioprocesses Research Unit, Cemagref, B.P. 44, 92163 Antony Cedex, \\ France.
}

* Corresponding author:

Sandrine Rosin-PAUMIER

Phone: +33 383596388

Fax: +33 383596300

E-mail: Sandrine.ROSIN@ensg.inpl-nancy.fr

\begin{abstract}
The solid-waste decomposition inside a municipal solid-waste (MSW) landfill may be enhanced by liquid addition in order to reach landfill stabilization in a reduced period of time as compared to dry-tomb landfills. This liquid addition provides an increased leachate volume and its specific chemical composition leads to fear a degradation of the hydraulic properties of the bottom liner system, especially the mineral part. In this study, the impact of four fluids on the chemical and hydraulic properties of three geosynthetic clay liners (GCLs) currently used in landfill bottom liner systems is evaluated using swelling tests, filter press tests and oedopermeameter tests. Each permeability test is associated to chemical analysis of the fluids before and after contact with the bentonites. The four fluids are two real leachates, a sewage
\end{abstract}


slurry and a leachate from a green waste repository. The three GCLs contain either natural sodium bentonite or sodium activated calcium bentonite.

Filter press results and swell index tests reveal a larger impact on the permittivity of the bentonite of leachates as compared to the other fluids. Oedopermeameter tests lasted one year; they show a variable impact, either negative or positive, of the real leachate on the hydraulic conductivity of the GCLs. Specific conditions, such as pre-hydration, limit the impact of leachate on the hydraulic conductivity. Whatever the method used to determine the permittivity of bentonite or of the GCL, the natural sodium bentonite is less impacted by the fluids than the sodium activated calcium bentonites.

Keywords: bentonite, bioreactor, cation, geosynthetic clay liner, hydraulic conductivity, landfill.

\section{INTRODUCTION}

Contrarily to the traditional dry-tomb landfill, the landfill bioreactor technology consists of the addition of moisture to the solid waste in order to create a favourable environment for the development of microorganisms responsible for solid waste decomposition. If optimal conditions are reached, this operation results into accelerated stabilization of the solid waste mass (Perera et al., 2005). However, the bioreactor process requires significant liquid addition to reach and maintain optimal conditions. Leachate alone is usually not available in sufficient quantity on a given landfill site to sustain the bioreactor process (Pacey et al., 2000). The addition to leachate of alternative fluids which may be available on the landfill site may thus be interesting (Grossin-Debattista, 2011; Pacey et al., 2000).

Considering the potential for future uses of alternative recirculation fluids and the increase of the leachate volume which may result in an increase in the hydraulic head on top 
of the composite bottom liner, the efficiency of the composite bottom liner system must be tested in these new conditions.

Geosynthetic clay liners (GCLs) have gained widespread popularity as substitute or reinforcement for compacted clay liners in composite landfill bottom liner systems (Bouazza, 2002; Touze-Foltz et al., 2008). In composite bottom liner systems in case the geomembrane overlying the GCL is damaged, an advective flow can occur through the defect, at the interface between the geomembrane and the GCL and subsequently through the GCL.

GCLs most often associate a bed of granular or powdered bentonite between two layers of geotextile, usually linked by needle punching or stitch bonding processes. Bentonite is a mixture of a variety of minerals, the predominant mineral being smectite clay (Patterson and Murray, 1983). Because the term "bentonite" is an industrial and not a mineralogical term, the quality of bentonites used in GCLs for landfill applications may vary to a large extent. For landfill bottom liner applications in France, it is recommended that sodium bentonite be used in GCLs, meaning that it is predominantly sodium ions which constitute the exchangeable cations of the bentonite (MEEDDAT, 2008). Sodium as the exchangeable cation may be the result of natural geological processes, like for Wyoming sodium bentonite, or else the result of activation process whereby calcium bentonite is mixed with volcanic soda ash, to force the calcium to sodium exchange. These materials are often called sodiumactivated calcium bentonites. This study allows comparing the impact of four fluids on one natural sodium bentonite and two sodium activated calcium bentonites.

Many laboratory studies aimed at quantifying the evolution of the hydraulic conductivity of GCLs in contact with various types of permeants such as real leachate from MSW landfills (Benson et al., 2008; Comeaga, 1997; Didier and Comeaga, 1995; Guyonnet et al., 2005; Han et al., 2009; Katsumi et al., 2008; Mlynarek, 1995; Shan and Lai, 2002), 
synthetic leachate (Jo et al., 2005; Joseph et al., 2001; Kostald et al., 2004; Lange et al., 2005; Petrov and Rowe, 1997) or both of them (Ruhl and Daniel, 1997; Schroeder et al., 2001). Hydraulic conductivity is measured either with flexible wall permeameters (ASTM, 2003, 2008) or rigid wall permeameters such as oedopermeameters (AFNOR, 2008). RosinPaumier et al. (2010a, 2010b) investigated the use of a filter press as a future way to quickly evaluate the potential interaction between a bentonite and a leachate. The filter press test is similar to the fluid loss test (ASTM, 2001) except that the effluent is collected all over the test in order to acquire a filtration curve which allows calculating the permittivity of the bentonite cake formed during testing (Pantet and Monnet, 2007). Rosin-Paumier et al. (2010a, b) compared the permittivities obtained from filter press tests and oedopermeameter tests on GCLs in contact with a $\mathrm{NaCl} 10^{-3} \mathrm{M}$ solution or a synthetic leachate respectively. Based on the results obtained with these two fluids, they concluded that the filter press tests may provide an indication on the fluid-bentonite interaction which can be correlated to the oedopermeameter tests results.

This study aims at evaluating the impact of four fluids sensed as potential efficient recirculation fluids on the hydraulic conductivity of three different GCLs.

The first recirculation fluid considered is leachate from municipal solid waste (MSW) landfills. However, the leachate chemical composition evolves according to the maturation of the solid waste; one can distinguish the succession of an acidogenic phase then a methanogenic phase (Han et al., 2009; Kjeldsen et al., 2002). Two leachates originating from two areas of the same landfill, an acidogenic leachate and a methanogenic leachate are thus studied. According to the recent investigation by Grossin-Debattista (2011), two alternative fluids, namely a sewage sludge and a fluid sampled on the collector of a green waste repository are also studied. 
In Section 2 of this paper, the GCLs, bentonites and fluids used are presented and the hydraulic and chemical tests used in this study are described. Section 3 will present the results obtained for each test. Results will be subsequently discussed in Section 4 of this paper.

\section{MATERIALS}

\subsection{Bentonites}

Three GCLs were selected among those currently used in composite MSW landfill bottom liner systems. LX1 is a stitch-bounded GCL consisting of a layer of bentonite and a nonwoven geotextile encapsulated between two woven geotextiles with masses per unit area around $110 \mathrm{~g} / \mathrm{m}^{2}$. LX2 and LX5 are needle-punched GCLs consisting of a layer of bentonite encapsulated between a non-woven $\left(220 \mathrm{~g} / \mathrm{m}^{2}\right)$ and a woven geotextile $\left(110 \mathrm{~g} / \mathrm{m}^{2}\right)$. One GCL (LX2) contained on average $5 \mathrm{~kg} / \mathrm{m}^{2}$ of natural sodium bentonite, whereas the other two GCLs (LX1, LX5) contained on average $5 \mathrm{~kg} / \mathrm{m}^{2}$ of sodium-activated calcium bentonites. These three bentonites were also studied by Guyonnet et al. (2009) and Rosin-Paumier et al. (2010a, b). The mineralogical content of each bentonite was described in detail by Guyonnet et al. (2009) and is not reported here.

The clay phase proportions, determined by Guyonnet et al. (2009), are in the range $68.8 \%$ to $76.5 \%$. The CEC values are in the range $75.4 \mathrm{meq} .100 \mathrm{~g}^{-1}$ to $94.1 \mathrm{meq} .100 \mathrm{~g}^{-1}$ for all bentonites (Table 1). The amount of removable sodium differs, according to the bentonite type, from $65.1 \%$ for the natural sodium bentonites to $80 \%$ on average for the sodiumactivated calcium bentonites. The amount of removable sodium is typically overestimated in the case of sodium-activated calcium bentonites, due to artefacts related to the dissolution of $\mathrm{NaHCO}_{3}$ added during the activation process (Guyonnet et al., 2009). 


\subsection{The permeation fluids}

Four fluids with contrasted chemical compositions were tested in this study (Table 2). These fluids were sensed to become efficient recirculation fluids according to their availability on the landfill site or their high methane productivity (Grossin-Debattista, 2011).

The acidogenic leachate (AL) and the methanogenic leachate (ML) were sampled in two different areas of the same MSW landfill (Vert-Le-Grand, France). AL comes from a part closed from less than two years, in which the solid waste was expected to be acidogenic. A comparison to data from the literature on the composition of acidogenic leachate (Ehrig, 1988), leads to the conclusion that this leachate was rather at an intermediate between acidogenic and methanogenic leachate as the calcium content of the leachate is lower than in data from the literature. ML comes from a part closed from more than five years so that the degradation is expected to be in a methanogenic phase. The ML composition revealed high potassium and ammonium content in comparison to data from the literature (Kjeldsen et al., 2002).

A Green Leachate (GL) was sampled on the collector of a green waste repository (Vert-Le-Grand, France). GL is a potassium-rich fluid. Moreover, its specific chemical composition may allow the degradation of the resistant carbon (Grossin-Debattista, 2011). The geographical proximity between the MSW landfill and the green waste repository may facilitate the recirculation of these fluids in the landfill.

The sewage sludge (SS) was collected at the digester outlet of a sewage treatment plant (Evry, France). The high content in methanogenic micro organisms of the sewage sludge may provide an earlier takeoff of the methanogenesis in the landfill (GrossinDebattista, 2011). Moreover the high ammonium content of SS was expected to enhance biogas production. 


\section{METHODS}

Swell index tests and filter press tests were used as quick methods to select fluids which would require extended study with oedopermeameter tests. Indeed, oedopermeameter tests were performed with the fluid inducing the smallest swell index and the larger hydraulic conductivity in the filter press test. The chemical compositions of the fluids were cautiously measured in order to detect a fluid-bentonite interaction. The various testing methodologies and measurement procedures are presented in the following subsections.

\subsection{Swell index tests}

Swell index tests are usually performed following XP P 84-703 (AFNOR, 2002) which is equivalent to ASTM D 5890 (ASTM, 2006), whereby two grams of dried and ground bentonite are dropped into $100 \mathrm{~mL}$ of water. The volume occupied by the bentonite is measured after $24 \mathrm{~h}$.

A quicker, simplified methodology previously used by Rosin-Paumier et al. (2010b) and consisting of inserting $0.2 \mathrm{~g}$ of bentonite into $10 \mathrm{~mL}$ of the various fluids under study was used. This procedure allows saving time as only a few increments are necessary to drop the bentonite into the fluid as compared to the standard procedures. Furthermore this solution is preferred as it allows reducing the risk of contamination in the laboratory by potentially dangerous fluids. Each test was duplicated. This simplified swell index was only used for indicative purposes.

\subsection{Filter press tests}

For the filter press tests, 40g of the bentonite extracted from LX1, LX2 and LX5 were dispersed in $400 \mathrm{~mL}$ of solution. The four solutions, namely AL, GL, SS and ML, were used 
for each bentonite. The dispersions were allowed to set for $24 \mathrm{~h}$ at rest. The filtration cell containing $300 \mathrm{~mL}$ of bentonite dispersion was subjected to a constant pressure of $700 \mathrm{kPa}$ by direct application of pressurised air. The cake intrinsic permeability, $K$, is determined using Darcy's law as described by Pantet and Monnet (2007). The protocol used was identical to the one previously presented in Rosin-Paumier et al. (2010a, 2010b) and will thus not be repeated here. Samples were tested in duplicate. Each experimental curve was evaluated, and the permittivity $\psi_{F P}$ reported herein represents the average of the two values. The mean deviation of the permittivities was $5.10^{-11} \mathrm{~s}^{-1}$. Oedopermeamters tests were then conducted with the three GCLs and the fluid which gave the largest permittivities, i.e., ML.

\subsection{Oedopermeameter tests}

The hydraulic conductivity values of the GCLs, $k_{O}\left(\mathrm{~m}^{-1}\right)^{-1}$, were determined at the end of a 100-kPa total confining stress step with an oedopermeameter as described in Guyonnet et al. (2005) in accordance with the procedures described in NF P 84-705 (AFNOR, 2008).

Entire GCLs including geotextiles and bonding were placed inside oeodopermeameter cells. Accordingly to the study conducted by Rosin-Paumier et al. (2010a, 2010b), tests began with a saturation phase, under $10-\mathrm{kPa}$, using a $1-\mathrm{mM} \mathrm{NaCl}$ solution under a zero hydraulic head. When at least $90 \%$ of the infinite swell was reached (determined according to AFNOR, 2008), the saturating liquid was replaced by one of the four fluids under study. Three total confining stresses of $25-\mathrm{kPa}, 50-\mathrm{kPa}$, and $100-\mathrm{kPa}$ were applied in three successive stages. Each stage lasted at least one month after application of the stress, which occurred within a few minutes. At the beginning of the $25-\mathrm{kPa}$ stage, a hydraulic head was applied to the specimens, starting with $0.3 \mathrm{~m}$ maintained for approximately one week, then $0.6 \mathrm{~m}$ during one week, and finally $1.2 \mathrm{~m}$. The hydraulic head was kept at $1.2 \mathrm{~m}$ during the last two confining pressure stages. 
As far as possible, the tests were not terminated before the following criteria were achieved (ASTM, 2002; Jo et al., 2005; Benson et al., 2008; Katsumi et al., 2008; Kolstad et al., 2004; Shackelford et al., 1999): (1) a steady hydraulic conductivity; (2) a ratio of incremental outflow to inflow (referred to herein as the "flow ratio") of approximately unity; (3) a minimum of two pore volumes of flow (PVF) passed through the specimen; and (4) ratios of effluent-to-influent electrical conductivity $(E C)$ and $\mathrm{pH}$ (herein referred to as the "EC ratio" and "pH ratio") within $1.0 \pm 0.1$. In addition, some authors (e.g., Jo et al. 2005) recommend comparing the concentration of specific chemical species between the influent (i.e., permeant liquid) and effluent (e.g., $\pm 10 \%$ ). Thus, the chemical compositions of the effluents and the influents were monitored during the tests using chemical analyses. Indeed, these measurements gave information on the reactivity of the GCL towards the permeant liquid inside the oedopermeameter cell.

Considering the aforementioned termination criteria, Benson et al. (2008) found that 6 to $8 \mathrm{PVF}$ were necessary to reach the $\mathrm{Na}^{+}$and $\mathrm{Al}^{3+}$ equilibrium for flexible-wall permeability tests performed with GCLs. Kolstad et al. (2004) conducted their tests beyond 15 to 20 PVF until each of the four termination criteria previously noted were achieved.

\subsection{Chemical analysis.}

At the end of the filter press tests $\mathrm{pH}$, electrical conductivity (EC) and chemical content were measured on the filtrates. Those measurements were also performed to check if the chemical equilibrium was reached in the case of the oedopermeameter tests. The $\mathrm{pH}$ was measured with a Metrohm Heris E $250 \mathrm{pH}$-meter standardized with buffer solutions at $\mathrm{pH} 7$ and $\mathrm{pH}$ 10. The EC of the dispersions, the effluents from filter press tests and oedopermeameter tests were measured with a Consort $\mathrm{k} 810$ conductimeter standardized with a buffer solution at $1413 \mu \mathrm{S} . \mathrm{cm}^{-1}$. 
Cation exchange capacity (CEC) and exchangeable cation composition were determined by exchange with cobaltihexamine, following NF X31-130 (AFNOR, 1999). Cobaltihexamine ions were quantified with a HITACHI U-200 spectrophotometer at a 475nm wavelength. Cationic contents were analyzed using an Ion Chromatography System DIONEX DX 120 equipped with a warmer analytical column CS16.

\section{$4 \quad$ RESULTS}

\subsection{Swell index tests}

The simplified swell indexes were determined for each bentonite and each fluid (see Table 3). Results are compared with similar tests realised on the same bentonites dropped in water (W) and a synthetic leachate (SL) (Rosin-Paumier et al., 2010b). A swell index lower than $10 \mathrm{~cm}^{3} .2 \mathrm{~g}^{-1}$ currently refers to an unswelling material or a material with a negligible swelling. The simplified swell index tests results are widespread, from less than $10 \mathrm{~cm}^{3} \cdot 2 \mathrm{~g}^{-1}$ for ML to $31 \mathrm{~cm}^{3} \cdot 2 \mathrm{~g}^{-1}$ for LX1 or LX2 dropped in W. Bentonites did not swell in ML. This result was identical to the one obtained with SL. The swelling of bentonites in AL, GL and SS were lower than the swelling in water. For each fluid, the swell index of LX5 is the smallest one.

From those results it can be deduced that among the four fluids under study ML is the most aggressive one for all bentonites.

\subsection{Permittivity tests}

\subsubsection{The filter press tests}

\section{The filtrate curves}

The filtrate curves obtained for each bentonite dispersed in each fluid are presented in Fig. 1. Each fluid provides an increase of the mass of filtrate in comparison with the filter press test realised on bentonites dispersed in water also reported on those graphs (Rosin- 
Paumier et al., 2010b). The filtrate masses collected during the SS or GL tests are, on average, 1.4 times larger than the filtrate mass collected during the $\mathrm{W}$ tests whatever the bentonite. AL has a larger impact than SS or GL considering that the AL filtrate masses are 1.4 to 2.3 times larger than the ones obtained in the tests performed with water. LX2 seems to be less sensitive than the other bentonites to AL as the filtration curve of LX2 dispersed in AL is identical to the filtration curve of LX2 dispersed in SS or GL.

The most dramatic increase in filtrate masses are observed with ML. The filtrate masses collected at the end of the ML tests are 3.6 to 5.3 times larger than the filtrate mass collected at the end of the W test. This huge impact may be compared with the impact of SL on the same bentonites (Rosin-Paumier et al., 2010b). Differences are observed depending on the bentonite tested. Indeed, similar filtration curves are obtained with ML and SL for LX1. On the contrary, for LX2 and LX5, the filtrate masses collected at the end of the SL tests were respectively 1.7 and 1.9 times larger than the filtrate masses collected at the end of the ML tests.

Permittivities of the bentonite in the filter press were determined using Eq. 1 for each filtration curve. Results are reported in Table 4 according to the composition of the permeant liquid. As expected, the lowest permittivities are obtained for the test performed with water (see $\psi_{\mathrm{FP}-\mathrm{W}}$ in table 4 ). For GL and SS tests, permittivities ranged from $7.16 \times 10^{-9} \mathrm{~s}^{-1}$ to $9.10 \times 10^{-}$ ${ }^{9} \mathrm{~S}^{-1}$ and exhibit a slight increase (1.1 to 1.3 times $\psi_{\mathrm{FP}-\mathrm{W}}$ ) as compared to the values of permittivity to water. Whatever the tested bentonite, the impact of GL and SS are small and close to each other. For the other fluids, the test results reveal contrasted impacts according to the tested bentonite consistently with results observed on Fig. 1. For AL tests, the permittivity of the natural sodium bentonite (LX2) is $7.83 \times 10^{-9} \mathrm{~s}^{-1}$ and the permittivities of the sodium activated calcium bentonites range from $1.18 \times 10^{-8} \mathrm{~s}^{-1}$ to $1.40 \times 10^{-8} \mathrm{~s}^{-1}$ with the largest value obtained with LX5. The permittivities to ML are the largest of all as they range from $1.87 \times 10^{-}$ 
${ }^{8} \mathrm{~s}^{-1}$ to $3.16 \times 10^{-8} \mathrm{~s}^{-1}$, which corresponds to 3.0 to 4.3 times $\psi_{\mathrm{FP}-\mathrm{W}}$. The largest permittivity is measured for LX1 and the lowest permittivity is measured for LX2. In comparison with the SL tests, the permittivity of LX5 dispersed in SL ( $\left.\psi_{\mathrm{FP}-\mathrm{SL}}\right)$ is equal to $\psi_{\mathrm{FP}-\mathrm{ML}}$ whereas $\psi_{\mathrm{FP}-\mathrm{SL}}$ for LX1 and LX2 are 1.7 to 2.0 times larger than $\psi_{\mathrm{FP}-\mathrm{ML}}$ respectively.

Whatever the composition of the solutions, the permittivities of the natural sodium bentonite dispersions are lower than those for the other bentonites dispersions. The largest permittivity is measured for LX1 dispersed in ML. However, according to the use of AL, LX5 provides the highest permittivity. Furthermore, the impact of a fluid was different according to the bentonite tested. The bentonite should thus be adapted to the fluid to contain.

\section{The chemical composition of the filtrates}

In order to try and explain the results obtained in the filter press tests, the chemical composition of each filtrate from filter press test was analysed (see Table 5). The comparison between the cationic composition of the permeant fluids (Table 2) and the cationic composition of the filtrates (Table 5) gives information on the bentonite-fluid chemical interaction inside the filter press cell.

Cations originate from the permeant fluid, the dissolution of the soluble salts and the cationic exchange inside the clay. The crystallisation of new species and some biological processes might modify the cationic content of dispersion but as contact time between the fluid and the bentonite is 25 hours, these impacts were neglected.

The bentonite of GCLs may exchange sodium for other cations if they are present in the fluids with which the GCLs come into contact.

Considering primary cations, namely sodium, ammonium and potassium, some modifications are noted between their initial concentrations (Table 2) and their concentrations in the effluents (Table 5). Sodium is released in excess for each test whereas ammonium and 
potassium are released in shortage. The differences between the concentrations in the initial fluids and the concentrations in the filtrates are different according to the tested fluid and the tested bentonite. Those results will be subsequently discussed.

A part of the sodium excess can be explained by the salt dissolution as highlighted by Rosin-Paumier et al. (2010b). However, this contribution is low in comparison with the huge increase in the effluents concentrations. For example, the sodium excess for SS reaches five times the sodium concentration measured for the same bentonite in water (Rosin-Paumier et al., 2010b).

The sodium release and the ammonium and potassium shortages may also originate from a modification of the clay saturation. Sodium from the exchangeable cations of the clay may be exchanged by ammonium or potassium. Such exchange may not modify the permittivity of the clay as potassium or ammonium saturation poorly modifies the clay layer structuration in comparison with sodium saturation (Verburg and Baveye, 1994). The chemical and hydraulic results for GL and SS tests match with this analysis.

The magnesium and calcium concentrations in SS and ML are low in comparison with the concentrations of the other cations namely sodium, ammonium and potassium. Moreover their concentrations in the filtrates are larger than their concentrations in the initial fluid. A cationic exchange of calcium and magnesium in the bentonites is thus not feared and thus cannot explain the high reactivity of the various bentonites to ML.

The magnesium and calcium concentrations in AL are 5 to 27 times lower than the concentration of the other cations. Moreover, their concentrations in the filtrates are at least $54 \%$ of the initial AL concentrations. These cations do probably not influence the result considering their low original concentration and the poor modification of these concentrations in the effluents. 
On the contrary, the magnesium and the calcium concentrations in GL are larger than the sodium and ammonium concentrations. Moreover, their concentrations in the filtrate are 7 to 33 times lower than their initial concentrations. A cationic exchange between sodium and these divalent cations may occur in case of the use of GL. However, filter-press test is a closed-circuit test so that cationic exchange is limited to the attempt of equilibrium. The dispersion of the bentonites in GL has thus no impact on the filter press permittivity.

Based on those results, the cation exchange cannot thus explain the high permittivities measured for ML tests as previously stated since the calcium and magnesium content in the filtrates are larger than in the initial fluid.

A phenomenon which could explain the results obtained in the filter press tests is the EC values. Indeed, in the case of ML, EC values of filtrates are 2.6 to 10.5 times larger than for the other filtrates (Table 5). Lagaly (2006) showed that a high salt concentration results in the collapse of the microstructure of the clay. As a result, the cake formation is disturbed and its permittivity increases. The permittivities measured for all tests are represented according to the electrical conductivities of the dispersions in Fig. 2. Results from Rosin-Paumier et al. (2010b) with the same bentonites dispersed in W and SL are also represented. Fig. 2 shows that a high calcium proportion or high electrical conductivity results in a pronounced increase of the cake permittivities.

Oedopermeameter tests were thus performed with ML which results in the larger permittivities in filter press tests and in the smallest swell index test results.

\subsubsection{The Oedopermeameter tests}

Figs. 3, 4 and 5 show the evolution of the inflow, outflow and GCL thickness during the oedopermeameter test performed respectively on LX1, LX2 and LX5 with ML as the permeant fluid. The permittivities of the GCLs were determined at the end of the test (Table 6) and compared to the permittivities determined by Guyonnet et al. (2009) over the same 
bentonites permeated with $\mathrm{NaCl} 1 \mathrm{mM}$ (Tab. 6). The effluent of the oedopermeameter tests were collected each week all along the tests. Their $\mathrm{pH}, \mathrm{EC}$ and cation compositions were also measured and analyzed (Fig. 6 and 7).

Thickness and flow rate evolution during the oedopermeameter tests.

Under the 25-kPa stage ( 0 to $0.7 \mathrm{PVF}$ ), the flow rate through LX1 reached $4.0 \times 10^{-}$ ${ }^{9} \mathrm{~m}^{3} / \mathrm{m}^{2} / \mathrm{s}$ (see Fig. 3 ) and the thickness was large (10.2mm). Under the 50-kPa stage (0.7 to 2 PVF), the thickness decreased to $10.0 \mathrm{~mm}$ and the flow rate gradually decreased to $3.7 \times 10^{-}$ ${ }^{9} \mathrm{~m}^{3} / \mathrm{m}^{2} / \mathrm{s}$. By the end of the $100-\mathrm{kPa}$ stage, which lasted ten months resulting in $12 \mathrm{PVF}$ crossing the GCL, the flow rate gradually decreased to reach $3.3 \times 10^{-9} \mathrm{~m}^{3} / \mathrm{m}^{2} / \mathrm{s}$ in the inflow and $3.9 \times 10^{-9} \mathrm{~m}^{3} / \mathrm{m}^{2} / \mathrm{s}$ in the outflow at steady-state. The resulting thickness of the GCL was $9.5 \mathrm{~mm}$. During the $100-\mathrm{kPa}$ stage, the outflow values lead to a cyclic evolution alternatively above then below the inflow values. This peculiar evolution may originate from a cycle of drain/storage in the GCL which can be the result of a gas development which distracts the correct flow of the effluent. Moreover, a technical problem at 10.2 PVF caused a decrease of the confining pressure. After the restoration of the test conditions, the inflow was constant but the outflow was 1.5 larger. The final permittivity was thus calculated on the inflow value rather than on the outflow values. At the end of the test, the permittivity of LX1 was estimated to be $2.70 \times 10^{-9} \mathrm{~s}^{-1}$.

Under the $25-\mathrm{kPa}$ stage, the flow rate in the outflow through LX2 was unstable, the inflow was $2.2 \times 10^{-9} \mathrm{~m}^{3} / \mathrm{m}^{2} / \mathrm{s}$ at the end of this stage and the thickness was $9.1 \mathrm{~mm}$ (see Fig. 4). Under the $50-\mathrm{kPa}(0.2$ to $1 \mathrm{PVF})$ then $100-\mathrm{kPa}$ stages, the flow rate gradually decreased to reach $1.8 \times 10^{-9} \mathrm{~m}^{3} / \mathrm{m}^{2} / \mathrm{s}$ in the inflow and $1.5 \times 10^{-9} \mathrm{~m}^{3} / \mathrm{m}^{2} / \mathrm{s}$ in the outflow at steady-state. By the end of the 100-kPa stage, which lasted nine months resulting in 8.5 PVF crossing the GCL, the permittivity reached $1.2 \times 10^{-9} \mathrm{~s}^{-1}$ at steady-state, and the resulting thickness of the GCL was $8.5 \mathrm{~mm}$. This test was duplicated. Results were similar regarding flow rate data and 
thickness data. The permittivity measured with this test is lower than the permittivity of LX2 permeated with $\mathrm{NaCl} 1 \mathrm{mM}$ (test realized by Guyonnet et al., 2009) (see Tab. 6). As a result, this test revealed no negative impact of ML on the LX2 hydraulic conductivity despite the long duration of the test (11 months). LX2 is the only GCL tested in this study which contains a natural sodium bentonite.

Two tests were performed with LX5. During the first test, the flow rate increased abruptedly at the beginning of the $25-\mathrm{kPa}$ confining stress stage so that the GCL became inefficient. The protocol for the second test was thus modified : (1) the $25-\mathrm{kPa}$ confining stress stage lasted 5 weeks ( 0 to 0.13 PVF) including 2 weeks applying a $0.1 \mathrm{~m}$ hydraulic head and 3 weeks applying a $0.3 \mathrm{~m}$ hydraulic head; (2) the 50-kPa confining stress stage lasted 3 weeks ( 0.13 to 0.6 PVF) including 1.5 week applying a 0.3 m hydraulic head and 1.5 week applying a $0.6 \mathrm{~m}$ hydraulic head; (3) the 100-kPa confining stress stage lasted 9 months including 1 week applying a $0.6 \mathrm{~m}$ hydraulic head, 2 weeks applying a $0.9 \mathrm{~m}$ hydraulic head and more than 8 months applying a $1.2 \mathrm{~m}$ hydraulic head. This testing procedure allowed measuring the flow rate all along the test without damaging the GCL. Each confining stress increase $(25-\mathrm{kPa}$ then $50-\mathrm{kPa}$ and $100-\mathrm{kPa})$ caused a pronounced decrease in the GCL thickness (see Fig. 5) and each modification of the hydraulic head (0.1 m then 0.3, 0.6, 0.9 and $1.2 \mathrm{~m}$ ) caused an increase in the flow rate but no modification of the GCL thickness. Under the $25-\mathrm{kPa}$ stage, the flow rate was $1.04 \times 10^{-9} \mathrm{~m}^{3} / \mathrm{m}^{2} / \mathrm{s}$ and the thickness was $7.7 \mathrm{~mm}$. Under the 50-kPa stage, the thickness decreased to $7.6 \mathrm{~mm}$ and the flow rate increased to 3.76 $\mathrm{x} 10^{-9} \mathrm{~m}^{3} / \mathrm{m}^{2} / \mathrm{s}$. By the end of the $100-\mathrm{kPa}$ stage, which lasted eight months, resulting in 20.5 PVF crossing the GCL, outflow rate values reached $4.2 \times 10^{-9} \mathrm{~m}^{3} / \mathrm{m}^{2} / \mathrm{s}$ at steady-state, the permittivity was $3.1 \times 10^{-9} \mathrm{~s}^{-1}$, and the resulting thickness of the GCL was $7.1 \mathrm{~mm}$.

For a similar time test, the impact of ML on the permittivity is different depending on the tested GCL. The permittivity of LX2 is constant. Neither the modification of the confining 
stresses nor the modifications of the hydraulic head had an impact on the hydraulic conductivity. The flow rate through LX5 is highly correlated to the confining stress and the hydraulic head applied to the specimen. Each modification in the hydraulic head resulted in a huge increase in the flow rate. This observation is worrying for the use of this GCL in the bottom layer of a solid waste disposal. Nevertheless, the LX5 flow rate is stable whenever the final hydraulic head was reached. The LX1 behaviour is intermediate. LX1 was not as sensitive to the hydraulic head as LX5 but an increase in the flow rate was measured during the $25-\mathrm{kPa}$ stage. However the flow rate decreases during the $50-\mathrm{kPa}$ stage to finally stabilize at a flow rate close to the flow rate measured by Guyonnet et al. (2009) over the same bentonite permeated with $\mathrm{NaCl} 1 \mathrm{mM}$ (see Tab. 6). The impact of the ML is thus different according to the considered GCL. The low bulk void ratios of LX5, $e_{b}$, calculated at the beginning of each oedopermeameter test (see Table 6), may facilitate the leachate permeation and explain its larger sensitivity to the permeation with ML. However, the $e_{b}$ of LX5 was close to the $e_{b}$ of LX2 and yet the LX5 flow rate was larger than the LX2 flow rate. The $e_{b}$ was thus not the sole factor explaining the leachate impact.

\section{The chemical composition of the effluents}

Effluents from the oedopermeameters are collected each week and analysed. Fig. 6 shows the evolution of EC ratio and $\mathrm{pH}$ ratio versus the number of PVF for each test. The $\mathrm{pHs}$ of the filtrates are larger than the ones of the permeants. The bentonites have thus a buffering impact. For each test, the $\mathrm{pH}$ ratio is approximately equal to 1.2 and remains constant all along the test. The ECs of the filtrates are clearly lower than the one of ML. The EC ratios are 0.4 at the beginning of the tests performed with LX2 and LX5. However the EC ratios increase all along the tests to reach $0.8,0.85$ and 0.87 at the end of tests performed with LX2, LX5 and LX1 respectively. For LX5, the EC reached equilibrium after 12 PVF. Despite the 
one year duration of the oedopermeameter tests, the ratios of effluent-to-influent $\mathrm{EC}$ and $\mathrm{pH}$ did not achieve the aforementioned criteria of $1.0 \pm 0.1$ (see Section 2.6).

Cation concentrations in the effluents are presented on Fig. 7. The composition of ML is represented by horizontal lines. The magnesium ratios increase along the first part of the test then decrease more or less quickly according to the GCL. At the end of the test, the magnesium ratios tend to 40 . The ammonium ratios increase all along the test, the ammonium concentrations exceed the initial ML concentration at almost 5 numbers of PVF. This ammonium excess may originate from a bacterial development inside the cell. The sodium ratios increase slightly during the tests then tends to 1 at the end of the tests. The potassium ratios are lower than 1 all along the tests but increase slowly. In the test performed with LX5, the potassium ratio tends to equilibrium at the end of the test. The calcium ratios decrease over the first part of the test, through four or five number of PVF. The initial value can be positive for LX2 and LX5, or negative for LX1. These values are not correlated neither with the carbonate content of the GCL nor the bentonite type. The chemical equilibrium is not reached at the end of the tests.

\section{DISCUSSION}

The filter press test and the oedopermeameter test are different in all respects (i.e. the material preparation, duration and confinement of the test, permeant renewal). It is thus not surprising to obtain contrasted results. The filter press test furnishes a single value for a dispersion at the chemical equilibrium in two days. It allows detecting differences between bentonites. The oedopermeameter test is a costly and long-duration test which needs a well-formed operator and further analyses to ensure the attempt of the termination criteria. However, it is a progressive test which presents three main advantages: (1) the confining stress and the hydraulic head can be adapted to the specific use of the GCL; (2) the GCL is used under its 
initial form including geotextiles and bonding process; (3) the open-chemical-system allows increasing the fluid/bentonite interaction by increasing the testing time.

Tab. 6 provides the permittivities obtained, for the oedopermeameter tests and filter press tests, on each bentonite contacted with ML (this study), $\mathrm{NaCl}$ (Guyonnet et al., 2009), a synthetic leachate (SL) or demineralised water (Rosin-Paumier et al., 2010b).

Oedopermeameter tests and filter press tests well both say that the natural sodium bentonite provided the lowest permittivities whatever the tested fluid.

Based on Rosin-Paumier et al. (2010b) the permittivity ratios from oedopermeameter tests, $R_{O}$, and from filter press tests, $R_{F P}$ were calculated:

$$
\begin{aligned}
& R_{O}=\frac{\psi_{O-F}}{\psi_{O-N a C l}} \\
& R_{F P}=\frac{\psi_{F P-F}}{\psi_{F P-W}}
\end{aligned}
$$

where $\psi_{F P-F}$ and $\psi_{F P-W}$ is the permittivity of the filter press cake based on a fluid $\mathrm{F}$ and demineralised water, respectively, and $\psi_{O-F}$ and $\psi_{\mathrm{O}-\mathrm{NaCl}}$ is the oedopermeameter based permittivity of the GCL using a fluid $\mathrm{F}$ and the 1-mM NaCl solution, respectively.

$R_{O}$ calculated for $\mathrm{ML}$ as the fluid $\mathrm{F}$ were 0.9 to 1.2 and $R_{F P}$ were 3 to 4.3 . The linear correlation was thus not verified. Indeed, the ML impact on the permittivity of the bentonites is measured as highly negative with filter press tests while it is measured as negligible or positive with the oedopermeameter tests. Those results are not thus consistent with previous results from Rosin-Paumier et al. (2010b) where $R_{O}$ appeared to increase linearly with $R_{F P}$ when SL. In conclusion thus liner trend cannot be generalised.

An important difference between the filter press or swell index tests and the oedopermeameter tests is the pre-hydration of the studied material. For oedopermeameter test, the GCL is pre-hydrated with $\mathrm{NaCl} 1 \mathrm{mM}$ solution during the swelling stage whereas the bentonites are dispersed in the contacting fluid for filter press or swell index test. The filter 
press test shows the impact of leachate on non prehydrated bentonites whereas the oedopermeameter test shows the impact of the leachate on a GCL in its best swelling conditions.

The oedopermeameter tests realised on three GCLs with a real leachate as permeant fluid (ML) provides a small negative impact (LX5), no impact (LX1) or a small positive impact (LX2) on the permeability of the GCLs in comparison with the same test realised with a neutral fluid as permeant fluid $(\mathrm{NaCl} 1 \mathrm{mM})$ (see Fig. 7). These results are in accordance with previous studies realised by permeation of a real leachates after a prehydration of the GCLs with neutral fluid as tap water (Didier and Comeaga, 1995; Norotte et al., 2004; Ruhl and Daniel, 1997; Schroeder et al., 2001; Shan and Lai, 2002).

Cation concentration measurements reveal a huge modification of the chemical composition between the permeant and the effluent. The ML has a pronounced impact on the material which does not result in an increase of the permeability in the time duration of the test but a long-term modification cannot be excluded.

The ML contains high potassium and ammonium concentrations. This huge ionization leads to a pronounced electrical conductivity of $28.9 \mathrm{mS} / \mathrm{cm}$, larger than the EC of others real leachates and of SL. This high EC can result in a collapse of the microstructure of the clay (Lagaly, 2006) as described in the filter press test. But the pre-hydration of the material in case of oedopermeameter tests avoids this degradation of the hydraulic properties of the clay.

Moreover, Guyonnet et al. (2005) realized oedopermeater tests on two GCLs prehydrated with $\mathrm{NaCl} 1 \mathrm{mM}$ then permeated with a real leachate. They observed that an ammonium rich leachate had a beneficial effect on the presence of a gel phase. The gel-phase was observed by transmission electron microscopy. It consists in individual clay layers or particles made of just a few clay layers separated by large distances. Guyonnet et al. (2005) showed that the larger proportions of gel phase detected by small angle X-Ray scattering, is 
consistent with the larger hydraulic conductivity measured with an oedopermeameter test. This positive impact may participate to the positive impact of ML on the permeability of the GCLs.

The flow rate decrease may also be the result of a biological development inside the oedopermeameter test. The biological clogging of porous media, often in conjunction with physical or chemical clogging, is encountered under a wide range of conditions including wastewater disposal (Baveye et al., 1998). Francisca and Glatstein (2010) show that inoculating bacteria and yeast in the compacting and permeating liquid reduced significantly the hydraulic conductivity of compacted silt-bentonite mixtures. This hypothesis was consolidated by two observations, especially for LX1 test: (1) the suspected gas development which distracts the correct flow of the effluent and (2) the continuous increased of the ammonium concentration in the filtrates from the oedopermeameter tests beyond the ammonium concentration of the initial fluid. A bacteriological or fungi development was able to clog the porosity and to provide a decrease of the permittivity (Baveye et al., 1998; Lekshmi and Sheela, 2009). This positive impact might participate to the positive impact of ML on the LX1 and LX2 permittivities.

The effluents to influents ratios of potassium and calcium were lower than the initial concentration on the filter press and the oedopermeameter filtrates. During the one year oedopermeameter tests, this decrease may be the result of complex chemical crystallization in the sample which is not expected to be the case during the one day filter press test. The calcium and magnesium decrease may indicate a cation exchange between the fluid and the exchangeable cations of the smectite. Those modifications in the saturation may result in a decrease of the permittivity value in a long term; this hypothesis was not verified herein.

Moreover, a potassium-saturation can induce the illitisation of the smectite which reduce it expandability (Howard, 1981). Consequently, the potassium shortage must be 
controlled in case of potassium-rich leachate. In our conditions, no impact was detected on the hydraulic conductivity, but the equilibrium was not reached even after one year of testing. In the real conditions, this phenomenon would probably occur over several years.

\section{CONCLUSION}

The objective of this paper was to investigate the impact of several fluids sense as became efficient circulation fluids on the permeability of GCLs containing natural sodium bentonite or sodium-activated calcium bentonites. Those fluids taken at a given time in the life of the site may not be representative of the chemical evolution of fluids with time and with the evolution of the composition of waste or sewage sludge.

The swell index tests and filter press tests provide similar results. They show a low impact of the sewage sludge and of the fluid from a green waste repository on the hydraulic properties of the tested bentonites.

The methanogenic leachate tested lead to the largest permittivities measured with filter press tests of all. This result can be surprising as the calcium concentration of this leachate was lower for example than the one of the acidogenic leachate. However, results obtained tend to show that not only the concentration in divalent cations but also the electrical conductivity of the leachate must be taken into account to predict the effect of a leachate on a bentonite.

Through the study performed thanks to filter press tests, different effects of a given fluid could be observed on the different bentonites. As a consequence, the nature of the bentonite must be adapted to the fluid to contain. In this study, the natural sodium bentonite provided the lowest permittivities whatever the tested fluid and the used method. However, the difference was often low and no generalisation should be performed based on a such few specimens. 
The methanogenic leachate, which seemed through swell index tests and filter press tests the most aggressive fluid of the four tested fluids, was used to perform one year oedopermeameter tests. The oedopermeameter tests results did not confirm the filter press tests results, i.e., no significant evolution in the hydraulic conductivities of the GCLs was noticed during the one year period. Indeed, only a small positive effect of ML on LX1 and LX2 and a small negative impact on LX5 test as compared to tests performed with water was detected at steady-state. However, the increase in flow rate in relation with an increase in hydraulic head for LX5 is worrying for the use of this GCL in landfill bottom liner systems.

Various hypotheses were proposed to explain the lack of confirmation of results obtained in filter press tests by results obtained in the oedopermeameter tests:

- the pre-hydration of the bentonite in case of oedopermeameter tests ;

- the high ammonium concentration in the leachate ;

- a biological clogging.

The oedopermeameter test should be performed with parallel tests with or without prehydration of the sample with $\mathrm{NaCl}$ to test the effect of the leachate on the swelling capacity and the permeability of the GCL.

The complex evolution of the chemical composition of the filtrates was not directly correlated to the flow rate evolution. No chemical equilibrium was reached despite the large test duration (one year) and the high number of PVF (8 to 20). However the chemical analyses of the filtrates from the permeation tests provide information on the potential retention and shortage of cations by the bentonite. For example, filter press tests show retention of divalent cations by the bentonite permeated with GL and SS. In the long-term, such retention may alter the swelling properties of the clay. The calcium, magnesium and potassium contents in the leachates must be controlled in case of the use of these fluids in MSW repository. On the contrary, such cation exchange was not feared for the permeation of 
the bentonites with ML since the calcium and magnesium content in the filtrates are larger than in the initial fluid.

\section{ACKNOWLEDGEMENTS}

This study was part of the Precodd Bioreacteur research program funded by ANR. The authors thank warmly A. Pantet from Laboratoire d'Etudes Aérodynamiques (LEA) of the Université de Poitiers, ENSMA, CNRS, France, for the equipment loan.

\section{REFERENCES}

AFNOR, 1999. NF X31-130. Détermination de la capacité d'échange cationique (CEC) et des cations extractibles. Association Française de Normalisation, Paris, France, 15p.

AFNOR, 2002. XP P 84 703. Détermination de la capacité de gonflement de l'argile dans les géosynthétiques bentonitiques. Association Française de Normalisation, Paris, France, $6 \mathrm{p}$.

AFNOR, 2008. NF P 84-705. Geosynthetic barriers - Determination of the swelling, flow and permeability characteristics of geosysnthetic clay liners (GCL) using an oedopermeameter - Characterisation test and performance test. Association Française de Normalisation, Paris, France, 21p.

ASTM, 2001. Standard D 5891. Standard test method for fluid loss of clay component of geosynthetic clay liners. ASTM International, West Conshohocken, 3p.

ASTM, 2002. Standard D 6766. Standard test method for evaluation of hydraulic properties of geosynthetic clay liners permeated with potentially incompatible liquids permeameter. ASTM International, West Conshohocken, 9p. 
ASTM, 2003. Standard D 5084. Standard test methods for measurement of hydraulic conductivity of saturated porous materials using a flexible wall permeameter. ASTM International, West Conshohocken, 23p.

ASTM, 2006. Standard D 5890. Standard Test Method for Swell Index of Clay Mineral Component of Geosynthetic Clay Liners. ASTM International, West Conshohocken, $4 \mathrm{p}$.

ASTM, 2008. Standard D 5887. Standard test method for measurement of index flux through saturated geosynthetic clay liner specimens using a flexible wall permeameter. ASTM International, West Conshohocken, $7 \mathrm{p}$.

Baveye, P., Vandevivere, P. , Hoyle, B. L. , DeLeo, P. C., de Lozada, D. S., 1998.

Environmental Impact and Mechanisms of the Biological Clogging of Saturated Soils and Aquifer Materials. Critical Reviews in Environmental Science and Technology, 28(2), 123-191.

Benson, C.H., Wang, X., Gassner, F.W., Foo, D.C.F., 2008. Hydraulic conductivity of two geosynthetic clay liners permeated with an aluminia residue leachate. Proceedings Geoamericas, Cancun, 2-5 March 2008, 94-101.

Bouazza, A., Zornberg, J.G., Adam, D., 2002. Geosynthetics in waste containment facilities: recent advances. Proceeding of Geosynthetics, $7^{\text {th }}$ ICG, Delmas, Gourc and Girard (eds), 445-507.

Comeaga, L., 1997. Dispositifs d'étanchéité par géosynthétiques bentonitiques dan les centres de stockage de dechets. PhD Thesis, Institut national des Sciences Appliquées de Lyon, France, 297p.

Didier, G., Comeaga, L., 1995. Influence of initial hydratation conditions on GCL leachate permeability. Testing and acceptance criteria for geosynthetic Clay Liner. American Society for Testing and materials, 1308, 181-195. 
Ehrig, H.-J., 1988. Water and element balances of Landfills. In The landfill, Baccini, P., Ed., Springer Verlag, Berlin, Germany, 1988 in Kjeldsen, 2002.

Francisca, F. M., Glatstein, D. A., 2010. Long term hydraulic conductivity of compacted soils permeated with landfill leachate. Applied Clay Science 49, 187-193.

Guyonnet, D., Gaucher, E., Gaboriau, H., Pons, C.-H., Clinard, C., Norotte, V., Didier, G., 2005. Geosynthetic clay liner interaction with leachate: correlation between permeability, microstructure, and surface chemistry. Journal of Geotechnical and Geoenvironmental Engineering 131, 740-749.

Guyonnet, D., Touze-Foltz, N., Norotte, V., Pothier, C., Didier, G., Gailhanou, H, Blanc, P., Warmont, F., 2009. Performance-based indicators for controlling geosynthetic clay liners in landfill applications. Geotextiles and Geomembranes 27, 321-331.

Grossin-Debattista, J., 2011. Fractionnements isotopiques $\left({ }^{13} \mathrm{C} /{ }^{12} \mathrm{C}\right)$ engendrés par la méthanogenèse : apports pour la compréhension des processus de biodégradation lors de la digestion anaérobie - Application aux procédés anaérobies de traitements des déchets non dangereux. $\mathrm{PhD}$ thesis, University of Bordeaux 1, Bordeaux, France, 250p. (in French)

Han, Y.-S., Lee, J.-Y., Miller, C.J., Franklin, L., 2009. Characterization of humic substances in landfill leachate and impact on the hydraulic conductivity of geosynthetic clay liners. Waste Management and Research 27(3): 233-241.

Howard, J.J., 1981. Lithium and potassium saturation of illite/smectite clays from interlaminated shales and sandstomes. Clays and clay Minerals 29, 136-142.

Jo, H.Y., Benson, C.H., Shackelford, C.D., Lee, J.M., Edil, T.B., ASCE, M., 2005. Long-term hydraulic conductivity of a geosynthetic clay liner permeated with inorganic salt solutions. Journal of Geotechnical and Geoenvironmental Engineering 131, 405-417. 
Joseph, J.B., Styles, J.R., Yuen, S.T.S., Cressey, G., 2001. Variations in clay mineral performance in the presence of leachates. Proceeding of the Eighth International Landfill Symposium, Sardinia, Italy, 10pp.

Katsumi, T., Ishimori, H., Fukagawa, R., 2008. Evaluating methods to modify the chemical resistance of geosynthetic clay liners. Geosynthetics in civil and environmental engineering. Proceeding $4^{\text {th }}$ Asian Regional Conference on Geosynthetics, Shanghai, China, Li, Chen and Tang (eds.), 526-531.

Kjeldsen, P. , Barlaz, M. A., Rooker, A. P., Baun, A., Ledin, A., Christensen, T. H., 2002. Present and Long-Term Composition of MSW Landfill Leachate: A Review. Critical Reviews in Environmental Science and Technology 32(4), 297-336.

Kolstad, D., Benson, C., Edil, T., 2004. Hydraulic conductivity and swell of nonprehydrated geosynthetic clay liners permeated with multispecies inorganic solutions. Journal of Geotechnical and Geoenvironmental Engineering 130, 1236-1249.

Lagaly, G., 2006. Colloid clay science, In Bergaya, F., Theng, B.K.G. and Lagaly, G. (Eds.), Handbook of Clay Science, Elsevier, 141-246 pp.

Lange, K., Rowe, R. K., Jamieson, H., 2005. Attenuation of Heavy Metals by Geosynthetic Clay Liners. Proceedings GeoFrontiers Conference, Austin, 8p.

Lekshmi, K. S., Sheela E. Y., 2009. Effect of Microbes on the Permeability of Bentonite. Proceeding $10^{\text {th }}$ National Conference on Technological Trends (NCTT09) 6-7 Nov, Kerala, India, College of Engineering Trivandrum (ed.), 100-104.

MEEDDAT - Ministère de l'Ecologie, de l'Energie, du Développement durable et de l'Aménagement du territoire, 2008. Guide de recommandations pour l'évaluation de l'équivalence en étanchéité passive d'installation de stockage de déchets, Version 2, 45p. 
Mlynarek, J., 1995. Revue de quelques aspects de l'application des geocomposites géosynthétiques/bentonite (GCL). In : Compte-rendu du séminaire Les Géocomposites Bentonitiques, Canada. Publication SAGEOS 9525a. 1-15 p.

Norotte, V., Didier, G., Guyonnet, D., Gaucher, E., 2004. Evolution of GCL hydraulic performance during contact with landfill leachate. In: Mackey, von Maubeuge (Eds.), Proceeding Advances in Geosynthetic Clay Liner Technology: 2nd Symposium, ASTM STP 1456. ASTM International,West Conshohocken, PA, pp. 41e52.

Pacey, J., Augenstein, D., Morck, R., Reinhart, D., Yazdani, R., 2000. The Bioreactor landfill - An Innovation in Solid Waste Management. SWANA Landfill Symposium, 14pp.

Pantet, A., Monnet, P., 2007. Liquide solid transition of kaolinite suspensions. Mechanics of Materials 39, 819-833.

Patterson, S.H., Murray, H.H., 1983. Clays, Industrial Minerals and Rocks, $5^{\text {th }}$ ed., Vol 1, S.J. Lafond (ed.), AIME New York, pp. 585-651.

Perera, N., van Everdingen, D., Davis, D., Hundal, J., Hettiaratchi, J.P.A., 2005. Bioreactor Landfills - An Innovative Technology for Biostabilization of Municipal Solid Waste. Proceeding of RemTech 2005, ESAA eds., Fairmont Banff Springs, Canada, 11pp.

Petrov, R.J., Rowe, R.K., 1997. Geosynthetic clay liner-chemical compatibility by hydraulic conductivity testing: factors impacting its performance. Canadian Geotechnical Journal 34(6), 863-885.

Rosin-Paumier, S., Touze-Foltz, N., Pantet, A., Monnet P., Didier, G., Guyonnet, D., Norotte, V., 2010a. Swell index, oedopermeametric, filter press and rheometric tests for identifying the qualification of bentonites used in GCLs. Geosynthetic International 17, 1-11. 
Rosin-Paumier, S., Touze-Foltz, N., Pantet, A., 2010b. Impact of a synthetic leachate on permittivity of GCLs measured by filter press and oedopermeameter tests. Geotextiles and Geomembranes 29, 211-221.

Ruhl, J. L., Daniel, D. E., 1997. Geosynthetic clay liners permeated with chemical solutions and leachates. ASCE J. Geotech. Geoenv. Eng., 123(4), 369-381.

Schroeder, A., Monjoie, A., Illing, P., Dosquet, D., Thorez, J., 2001. Testing a factoryprehydrated GCL under several conditions, In: Proceedings of the International $8^{\text {th }}$ International Waste management and landfill symposium, Sardinia, Vol III, 149-157.

Shackelford, C., Malusis, D., Majeski, M., Stern, R., 1999. Electrical conductivity breakthrough curves. Journal of Geotechnical and Geoenvironmental Engineering 125, $260-270$.

Shan, H. Y., Lai, Y. J., 2002. Effect of hydrating liquid on the hydraulic properties of geosynthetic clay liners. Geotextiles and Geomembranes, 20, 19-38.

Touze-Foltz, N., Lupo, J., Barroso, M., 2008. Geoenvironmental applications of geosynthetics. Keynote lecture, Proceedings EuroGeo4, 98 pp.

Verburg, K., Baveye, P., 1994. Hysteresis in the binary exchange of cations on 2:1 clay minerals; a critical review. Clays and Clay Minerals 42, 207-220. 


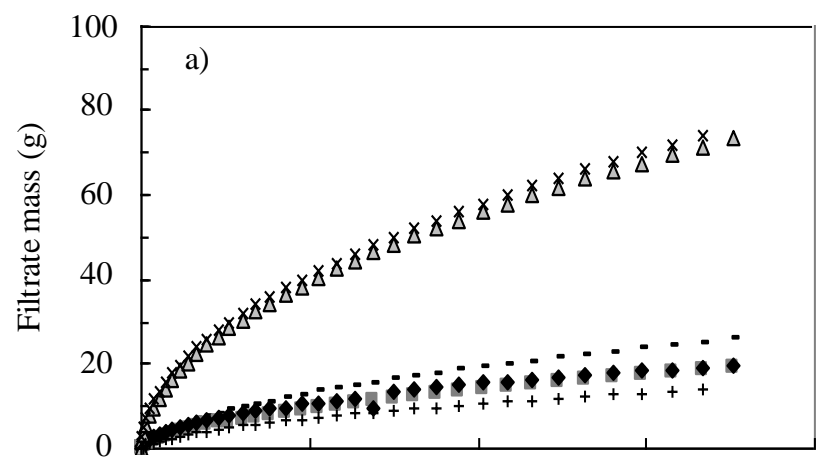

Fluids : + W

- SS

- GL

$-\mathrm{AL}$

$\triangle$ ML

$\times$ SL



Fig. 1: Filtration curves for a) LX1; b) LX2 and c) LX5 dispersed in AL, SS, GL, ML (this study), osmosed water (W) and a synthetic leachate (SL) curves are from Rosin-Paumier et al. (2010b). 




Fig. 2: Permittivities obtained with the filter press under a $700 \mathrm{kPa}$ air pressure according to the electrical conductivity of the dispersion. SL and W points were performed by RosinPaumier et al. (2010b). 

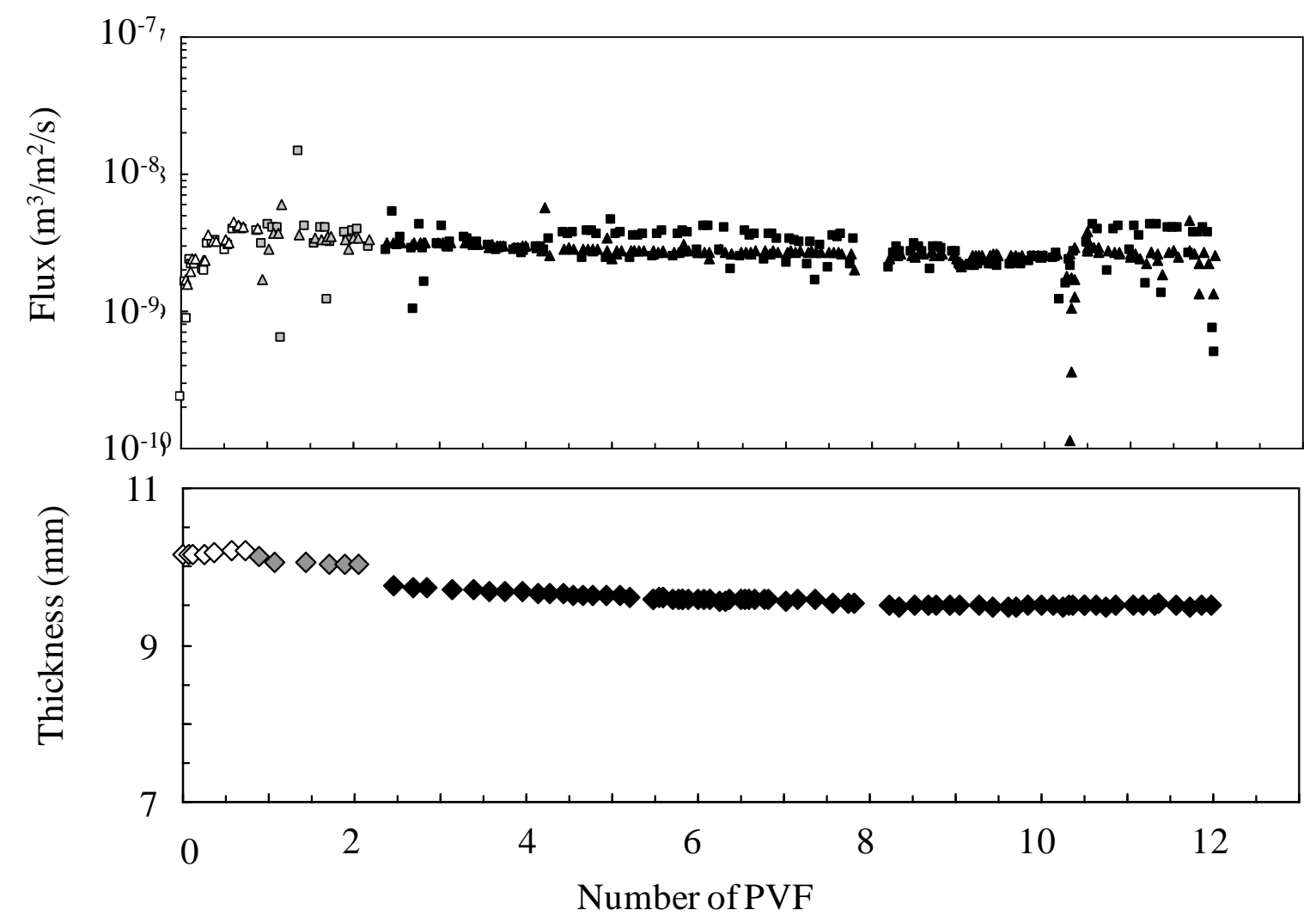



Fig. 3: Evolution of the permittivity and the GCL thickness of LX1 according to the number of PVF during the ML oedopermeameter test. 

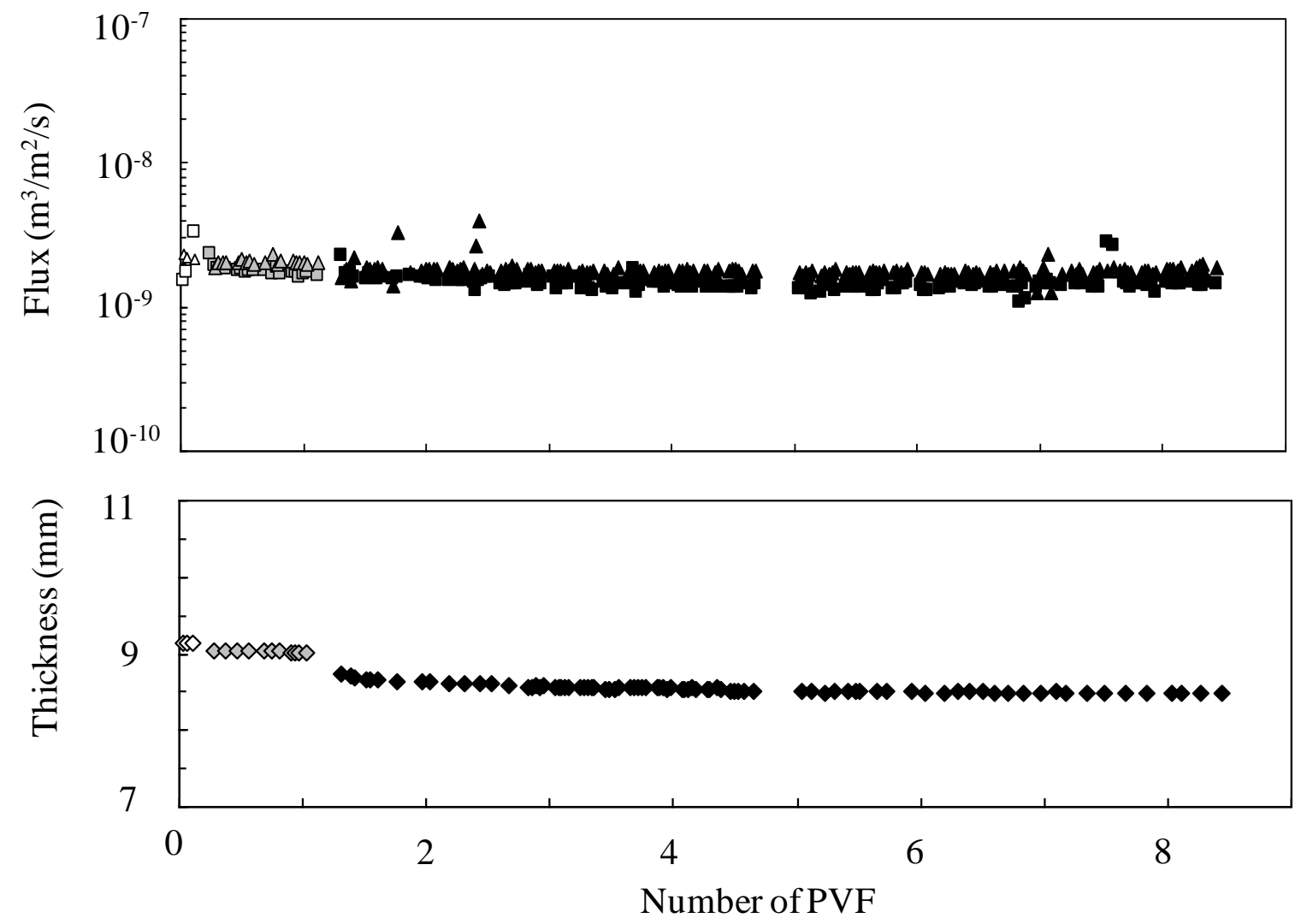
$\Delta \Delta \boldsymbol{\Delta}$ inflow
ㅁ D outflow
$\diamond \diamond \diamond$ GCL's thickness
Confining pressure: $\Delta \square \diamond 25 \mathrm{kPa}$
$\Delta \square \diamond 50 \mathrm{kPa}$
$\Delta \boldsymbol{\square} 100 \mathrm{kPa}$

Fig. 4: Evolution of the permittivity and the GCL thickness of LX2 according to the number of PVF during the ML oedopermeameter test. 

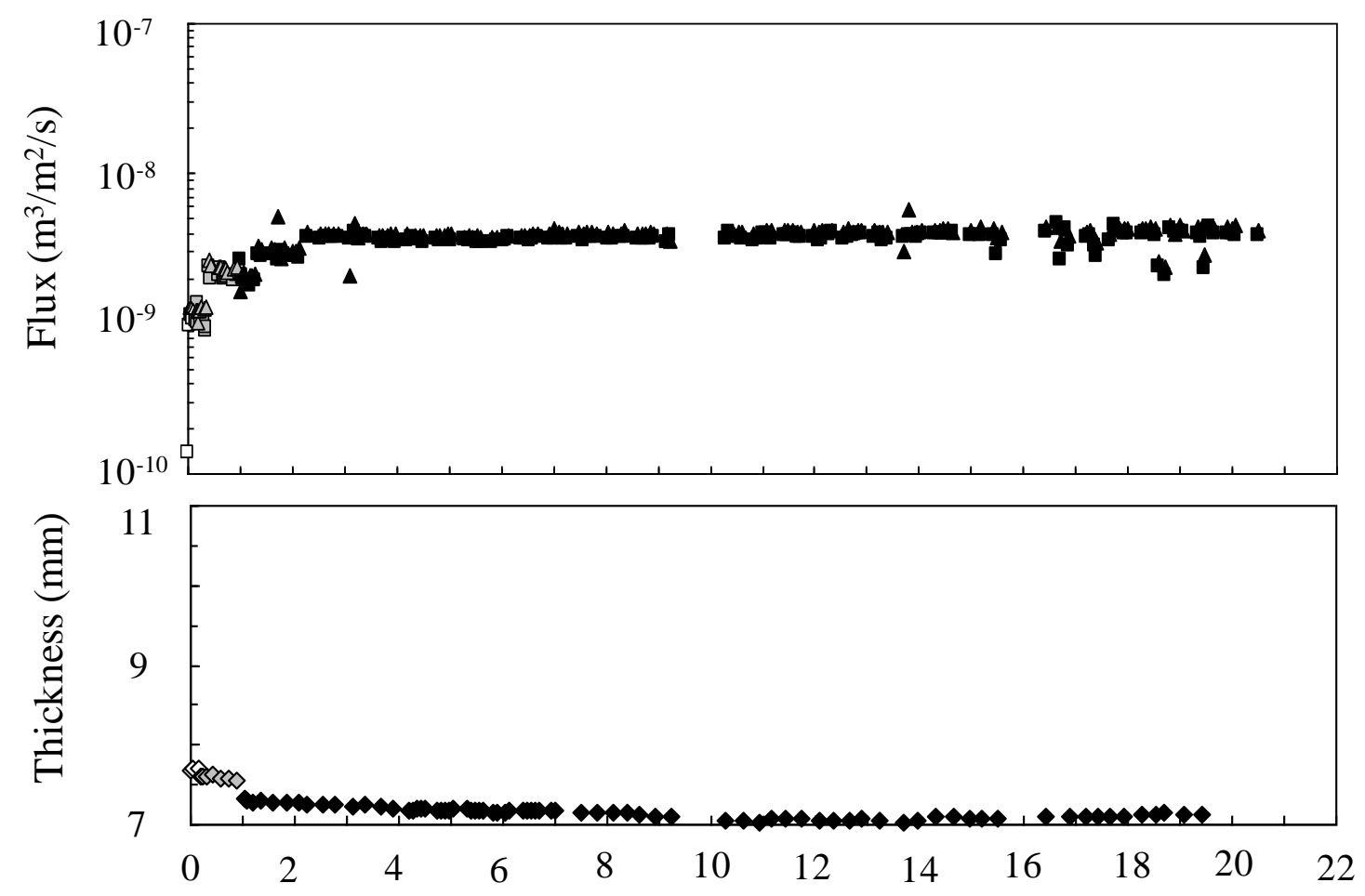

Number of PVF

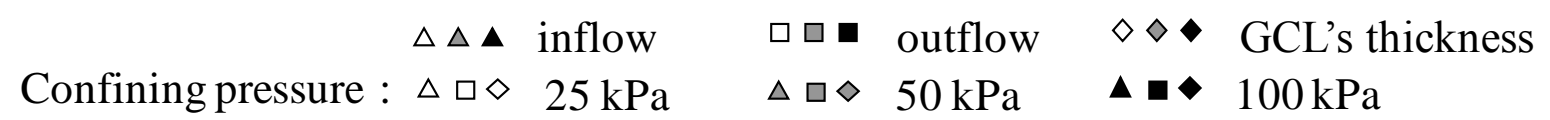

Fig. 5: Evolution of the permittivity and the GCL thickness of LX5 according to the number of PVF during the ML oedopermeameter test. 


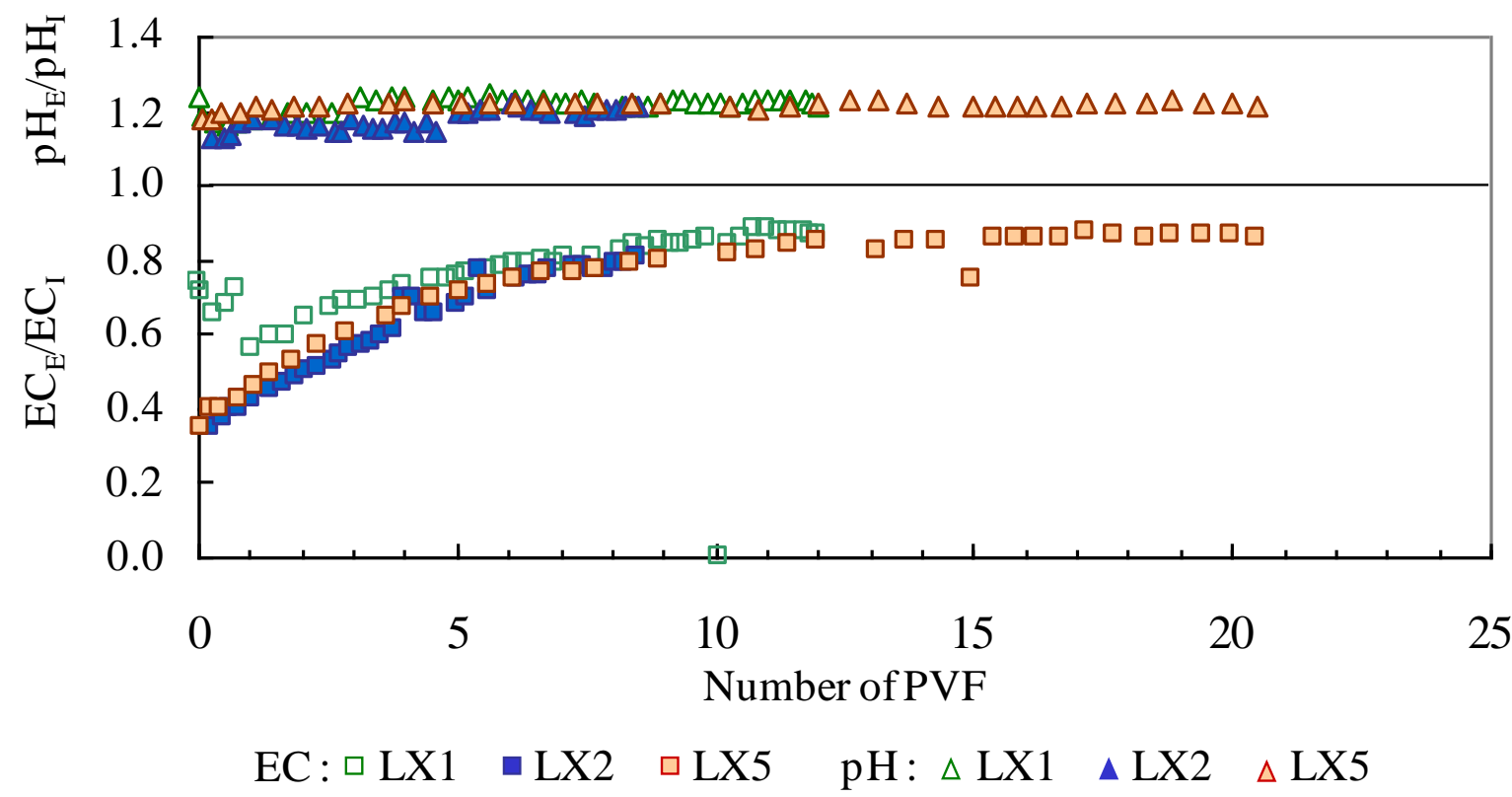

Fig. 6: Effluent-to-influent ratio of $\mathrm{EC}$ and $\mathrm{pH}$ during the oedopermeameter tests according to the number of PVF. 
a)

b)
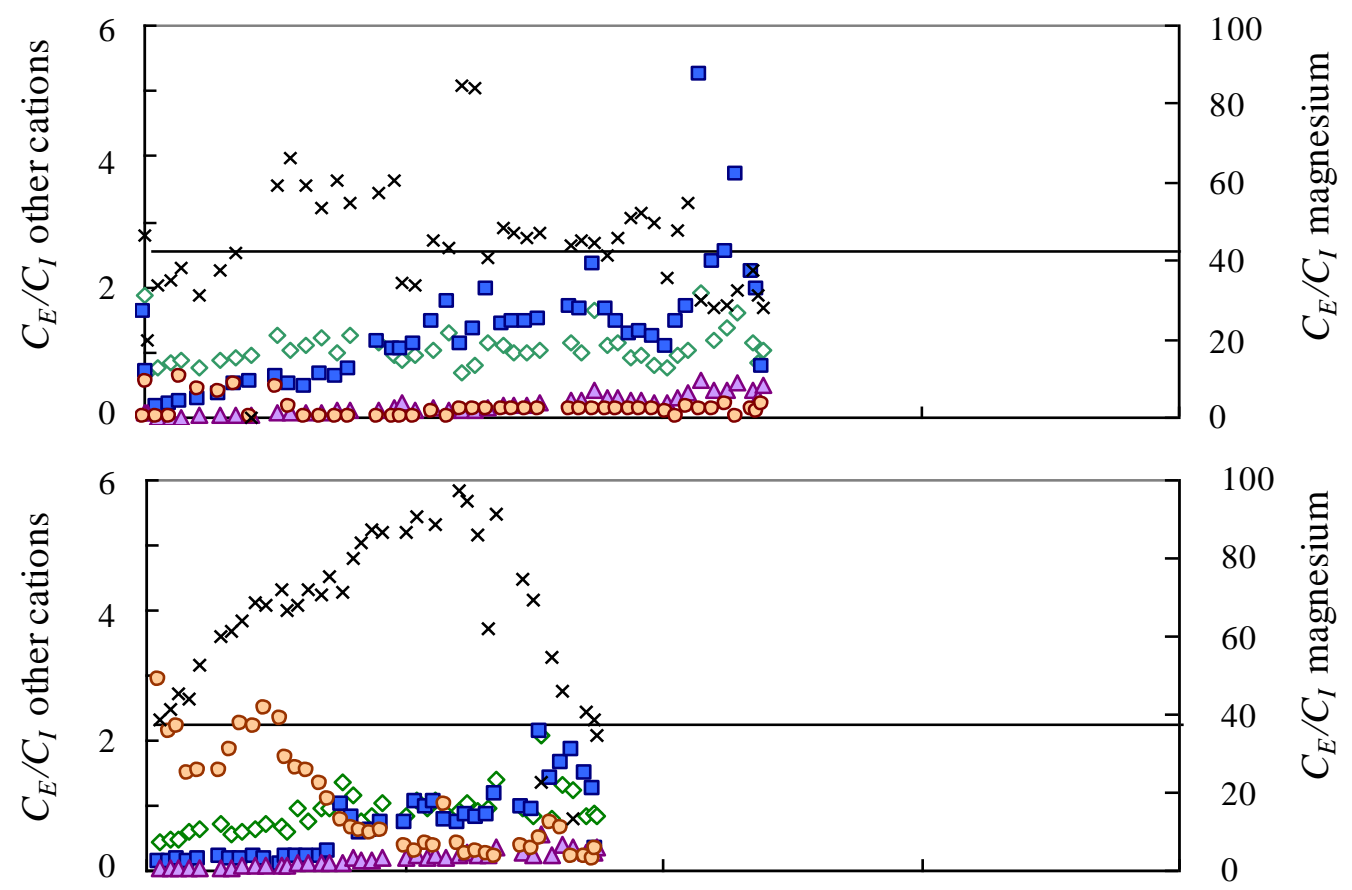

c)

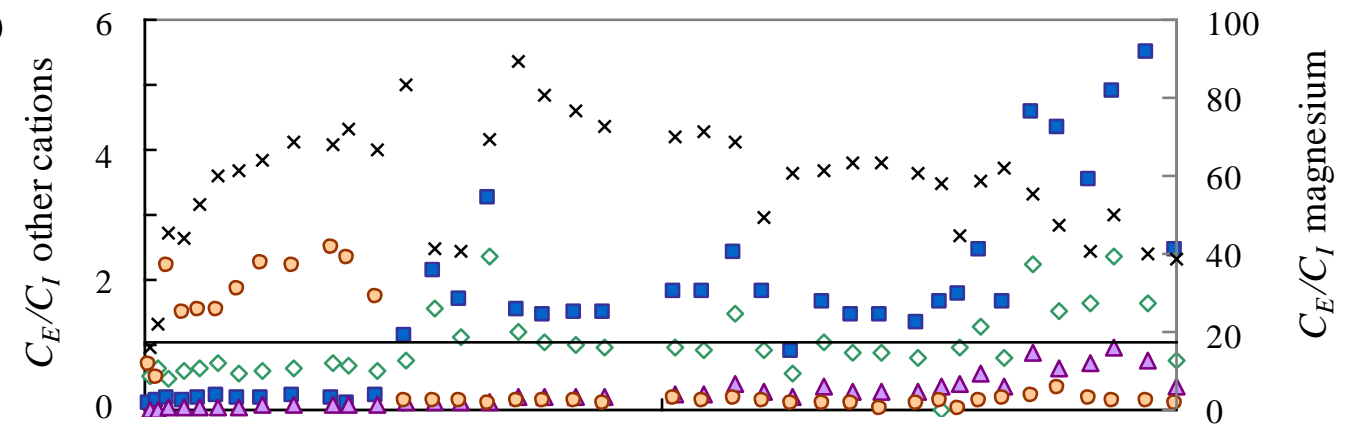

0

5

10

15 20

Number of PVF
$\diamond$ Sodium
Ammonium
$\triangle$ Potassium
$\times$ Magnesium
o Calcium

志

Fig. 7: Effluent-to-influent ratio of the cation concentrations $\left(C_{E} / C_{I}\right)$ according to the number of PVF for oedopermeameter tests realised on: (a) LX1; (b) LX2; and (c) LX5 permeated by ML. 
Table 1: Chemical characterization of the bentonite include in the GCLs.

\begin{tabular}{lcccccc} 
& CEC & \multicolumn{4}{c}{ Extractibles cations $\left({\mathrm{mg} . \mathrm{L}^{-1}}^{-1}\right.$} \\
& Meq.100g & $\mathrm{Na}^{-}$ & $\mathrm{NH}_{4}^{+}$ & $\mathrm{K}^{+}$ & $\mathrm{Mg}^{2+}$ & $\mathrm{Ca}^{2+}$ \\
\hline LX1 & 91.8 & 36.8 & $<\mathrm{d}$ & $<\mathrm{d}$ & 1.1 & 4.5 \\
LX2 & 75.4 & 21.2 & 1.2 & $<\mathrm{d}$ & 0.5 & 7.8 \\
LX5 & 94.1 & 32.7 & 2.2 & 0.2 & 1.6 & 5.5
\end{tabular}

Note: $\mathrm{CEC}=$ cation exchange capacity

$<\mathrm{d}$ : under detection 
Table 2: Cationic composition $\left(\mathrm{mg} . \mathrm{L}^{-1}\right), \mathrm{pH}$ and Electrical conductivities $(\mathrm{mS} / \mathrm{cm})$ of the acidogenic leachate (AL), the green leachate (GL), the sewage sludge (SS), the methanogenic leachate (ML) and the synthetic leachate (SL).

\begin{tabular}{lccccccccc} 
& $\mathrm{Na}^{+}$ & $\mathrm{NH}_{4}{ }^{+}$ & $\mathrm{K}^{+}$ & $\mathrm{Mg}^{2+}$ & $\mathrm{Ca}^{2+}$ & $\mathrm{Cl}^{-}$ & $\mathrm{SO}_{4}{ }^{2-}$ & $\mathrm{pH}$ & $\mathrm{EC}$ \\
\hline $\mathrm{AL}$ & 877 & 1220 & 1016 & 162 & 46 & 1363 & 194 & & \\
$\mathrm{GL}$ & 55 & 7 & 562 & 33 & 111 & 282 & $<\mathrm{d}$ & 6.78 & 1.9 \\
$\mathrm{SS}$ & 84 & 1095 & 81 & 32 & 35 & 170 & $<\mathrm{d}$ & 6.85 & 7.97 \\
$\mathrm{ML}$ & 5683 & 2856 & 4132 & $<\mathrm{d}$ & 24 & 5397 & 21 & 8 & 29 \\
$\mathrm{SL}$ & 690 & 720 & 665 & 365 & 1042 & 3474 & 480 & 7.1 & 13.3
\end{tabular}

Note: <d: under detection 
Table 3: Simplified swell index $\left(\mathrm{cm}^{3} .2 \mathrm{~g}^{-1}\right)$ of each bentonite in ML, GL, SS and AL (this study) and in W and a synthetic leachate, namely SL (Rosin-Paumier et al., 2010b).

\begin{tabular}{lccc} 
& LX1 & LX2 & LX5 \\
\hline ML & $<10$ & $<10$ & $<10$ \\
GL & 20 & 20 & 18 \\
SS & 20 & 14 & 14 \\
AL & 16 & 19 & 16 \\
W & 31 & 31 & 21 \\
SL & $<10$ & $<10$ & $<10$
\end{tabular}


Table 4: Permittivities $\left(\mathrm{s}^{-1}\right)$ obtained in filter press tests with the four bentonites (LX1, LX2 and LX5) dispersed in AL, GL, SS, ML, SL and DW.

\begin{tabular}{lccc} 
& LX1 & LX2 & LX5 \\
\hline AL & $1.18 \times 10^{-8}$ & $7.83 \times 10^{-9}$ & $1.40 \times 10^{-8}$ \\
GL & $8.50 \times 10^{-9}$ & $7.16 \times 10^{-9}$ & $7.82 \times 10^{-9}$ \\
SS & $8.69 \times 10^{-9}$ & $7.48 \times 10^{-9}$ & $9.10 \times 10^{-9}$ \\
ML & $3.16 \times 10^{-8}$ & $1.87 \times 10^{-8}$ & $2.50 \times 10^{-8}$ \\
SL & $3.24 \times 10^{-8}$ & $3.18 \times 10^{-8}$ & $4.93 \times 10^{-8}$ \\
DW & $7.36 \times 10^{-9}$ & $6.16 \times 10^{-9}$ & $6.98 \times 10^{-9}$
\end{tabular}


Table 5: $\mathrm{pH}$, electrical conductivity $(\mathrm{EC}, \mathrm{mS} / \mathrm{cm})$ and cation concentration $(\mathrm{mg} / \mathrm{l})$ in the filtrate at the end of each filter press test performed on bentonites from LX1, LX2 and LX5 dispersed in AL, GL, SS, ML, SL and DW. XX $\mathrm{n}_{\mathrm{n}}$ means bentonite LXn dispersed in fluid XX.

\begin{tabular}{lccccccc} 
& $\mathrm{Na}^{+}$ & $\mathrm{NH}_{4}^{+}$ & $\mathrm{K}^{+}$ & $\mathrm{Mg}^{2+}$ & $\mathrm{Ca}^{2+}$ & $\mathrm{pH}$ & $\mathrm{EC}$ \\
\hline $\mathrm{AL}_{1}$ & 2163 & 542 & 325 & 104 & 28 & 7.4 & 10.0 \\
$\mathrm{AL}_{2}$ & 1714 & 679 & 551 & 85 & 25 & 7.1 & 8.8 \\
$\mathrm{AL}_{5}$ & 1833 & 454 & 309 & 101 & 35 & 7.3 & 9.8 \\
\hline $\mathrm{GL}_{1}$ & 1000 & 1 & 37 & 3 & 10 & 8.6 & 3.9 \\
$\mathrm{GL}_{2}$ & 552 & 7 & 70 & 3 & 17 & 8.0 & 2.7 \\
$\mathrm{GL}_{5}$ & 839 & 7 & 33 & 1 & 10 & 8.5 & 3.5 \\
\hline $\mathrm{SS}_{1}$ & 2122 & 704 & 84 & 44 & 70 & 7.7 & 7.7 \\
$\mathrm{SS}_{2}$ & 1408 & 836 & 120 & 31 & 41 & 7.4 & 6.2 \\
$\mathrm{SS}_{5}$ & 2175 & 750 & 11 & 54 & 38 & 7.4 & 7.3 \\
\hline $\mathrm{ML}_{1}$ & 6840 & 1619 & 1513 & 79 & 36 & 7.8 & 28.1 \\
$\mathrm{ML}_{2}$ & 6525 & 2140 & 1910 & 74 & 94 & 7.6 & 25.7 \\
$\mathrm{ML}_{5}$ & 5969 & 2015 & 1288 & 109 & 44 & 8.1 & 27.6 \\
\hline $\mathrm{SL}_{1}$ & 2449 & 561 & 416 & 273 & 502 & 7,7 & 14.6 \\
$\mathrm{SL}_{2}$ & 1768 & 633 & 570 & 296 & 839 & 7.5 & 13.9 \\
$\mathrm{SL}_{5}$ & 2335 & 563 & 395 & 301 & 592 & 7.8 & 14.3 \\
\hline $\mathrm{DW}_{1}$ & 409 & 0 & 2 & 0 & 2 & 9.5 & 2.4 \\
$\mathrm{DW}_{2}$ & 180 & 8 & 3 & 0 & 1 & 8.9 & 0.9 \\
$\mathrm{DW}_{5}$ & 338 & 0 & 2 & 1 & 2 & 9.2 & 1.6 \\
\hline
\end{tabular}


Table 6: Hydraulic conductivity $k_{O}\left(\mathrm{~m}_{.} \mathrm{s}^{-1}\right)$ and permittivities $\psi_{\mathrm{O}}\left(\mathrm{s}^{-1}\right)$ of LX1, LX2 and LX5 permeated with ML ( $\left.\mathrm{ML}_{1,2,5}\right)$, SL $\left(\mathrm{SL}_{1,2,5}\right)$ or $\mathrm{NaCl} 1 \mathrm{mM}\left(\mathrm{NaCL}_{1,2,5}\right)$ during PVF obtained in the oedopermeameter tests under a 100kPa confining stress and a hydraulic head of $1.2 \mathrm{~m}$.

\begin{tabular}{lccccc} 
& $k_{O}$ & $\psi_{o}$ & $\mathrm{PVF}$ & $e_{b}$ & $m_{b}$ \\
\hline $\mathrm{ML}_{1}$ & $2.06 \times 10^{-11}$ & $2.70 \times 10^{-9}$ & 12.0 & 2.72 & 6.14 \\
$\mathrm{ML}_{2}$ & $1.03 \times 10^{-11}$ & $1.21 \times 10^{-9}$ & 8.5 & 2.11 & 6.08 \\
$\mathrm{ML}_{5}$ & $2.25 \times 10^{-11}$ & $3.15 \times 10^{-9}$ & 20.5 & 2.01 & 5.34 \\
\hline $\mathrm{SL} 1$ & $2.94 \times 10^{-11}$ & $3.2 \times 10^{-9}$ & 1.8 & & \\
$\mathrm{SL} 2$ & $4.60 \times 10^{-11}$ & $5.70 \times 10^{-9}$ & 6.6 & & \\
$\mathrm{SL5}$ & $1.06 \times 10^{-10}$ & $2.11 \times 10^{-8}$ & 40.1 & & \\
\hline $\mathrm{NaCl}_{1}$ & $2.40 \times 10^{-11}$ & $2.79 \times 10^{-9}$ & 3.4 & & \\
$\mathrm{NaCl}_{2}$ & $1.2 \times 10^{-11}$ & $1.3 \times 10^{-9}$ & 2.1 & & \\
$\mathrm{NaCl}_{5}$ & $1.9 \times 10^{-11}$ & $2.5 \times 10^{-9}$ & 3.5 & &
\end{tabular}

Notes: PVF $=$ pore volumes of flow

$e_{b}=$ bulk void ratio of each bentonite at the beginning of the test $m_{b}=$ Mass per unit area of dry bentonite in the GCL $\left(\mathrm{kg} \cdot \mathrm{m}^{-2}\right)$ 